3 Wang HH, Antonioli DA, Goldman H. Comparative features of esophageal and gastric adenocarcinomas: recent changes in type and frequency. Hum Pathol 1986; 17: 482-7.

4 Jankowski J, McMenemin R, Hopwood D, Penston J, Wormsley KG. Abnormal expression of growth regulatory peptides and their receptor in Barrett's mucosa. Clin Sci 1991; 81: 663-8.

5 Jankowski J, Hopwood D, Wormsley KG. Flow cytometric assessment of growth regulatory peptides in Barrett's mucosa. Scand f Gastroenterol 1992; 27: 147-54

\section{Omeprazole versus ranitidine in the treatment of resistant duodenal ulce}

SIR, - Bardhan et al have clearly demonstrated the benefit of omeprazole in the therapy of refractory peptic ulcer (Gut 1991; 32: 435-8). It is well known that about $5-10 \%$ of peptic ulcers do not heal when treated with $\mathbf{H}_{2}$ antagonists and are considered to be refractory. The optimal management of these patients is not yet established. Published data are contradictory about the efficacy of omeprazole therapy in patients with peptic ulcer that are resistant to the $H_{2}$ receptor antagonist treatment. $^{12}$

It is important, therefore, to take into consideration all experiences which could help us to find the best treatment. We have conducted a controlled randomised study to assess the efficacy of omeprazole $40 \mathrm{mg}$ daily compared with ranitidine continued at the same dose in patients with duodenal ulcers that were refractory to the previous ranitidine treatment. Forty five outpatients were treated during this study. Patients with a duodenal ulcer of at least $5 \mathrm{~mm}$ diameter which did not heal after six weeks' treatment with $300 \mathrm{mg}$ ranitidine were admitted to the trial. Endoscopy, performed at the beginning of the trial, showed active duodenal ulcer in all cases. Patients were randomly allocated to two groups - in 23 the ranitidine therapy was continued in the same dose ( $150 \mathrm{mg}$ twice a day) and in 22 omeprazole $40 \mathrm{mg}$ was given at bedtime. All patients received antacids for pain relief. No other antiulcer treatment was allowed.

The two groups were not significantly different as to age, duration of ulcer disease, smoking habits and alcohol consumption. Control endoscopy was carried out after 4 weeks' treatment. Omeprazole was significantly better than continued ranitidine therapy in healing rates of duodenal ulcers at the four week contro endoscopy (healing rates: omeprazole group 19 $(86 \%)$ patients; ranitidine $11(50 \%)$ patients $\chi^{2}$ test: $\left.7.81 ; \mathrm{p}<0.01\right)$. Omeprazole also gave better symptom relief than ranitidine. No side effects were reported and all patients completed the study

Patients with unhealed ulcers received omeprazole ( $40 \mathrm{mg}$ at bedtime) for a further four weeks. At the end of this period endoscopy was repeated and showed healed ulcer in all three patients from the omeprazole group and in nine of 12 patients from the ranitidine group.

Our results indicate that omeprazole is more effective in patients with duodenal ulcer that fail to heal with ranitidine treatment. Our findings agree with those of Bardhan et al, although in our study the previously unsuccessful $\mathbf{H}$-receptor antagonist therapy was conducted with the same drug, and at the same dose in all cases and only patients with duodenal ulcer were included to the study.

Our results, obtained from strictly defined subset of patients with duodenal ulcer, confirm that omeprazole has a significant beneficial effect in the management of resistant duodenal ulcers.

\section{Z TULASSAY \\ F SZALAY \\ $M$ ACHARYA \\ Department of Internal Medicine, Semmelweis University Medical School, Budapest, Hungary blind multicentre comparison of omeprazole $20 \mathrm{mg}$ once daily versus ranitidine $150 \mathrm{mg}$ twice daily in the treatment of cimetidine or ranitidin resistant duodenal ulcers. Gut 1989; 30: 1173-8. ulceration resistant to extended high dose ranitidine treatment. Digestion 1988; 39: 80-90.}

1 Delchier JC, Isal JP, Eriksson S, Soule JC. Double 2 Brunner G, Creutzfeldt W, Harke V, Laberts R. Therapy with omeprazole in patients with peptic

\section{BOOK REVIEWS}

Diarrheal diseases. By Michael Field. (Pp 538; illustrated; US\$72.) New York: Elsevier, 1991

This is just the sort of book that I wished that I had edited myself. To be truthful I nearly did except the idea of writing a book on 'Diarrhoea' was turned down by two publishers on the grounds that it was 'too specialised'. I am delighted that Michael Field has pulled it of and produced such a superb product. He has assembled approximately 30 experts in scientific and clinical aspects of diarrhoea from both sides of the Atlantic. The structure of the book is utterly logical moving from molecula mechanisms of diarrhoea through pathophysiology into two clinical sections describing the nature of clinically important diarrhoeal disease and their treatment. The book is a powerful data base for all those involved in laboratory and clinical research into diarrhoea diseases. All chapters are extremely well referenced containing on average a hundred or more references. Most chapters are well illustrated although a few suffer from dense unrelenting text but the content is invariably of high quality.

I have few serious criticisms. Despite the impressive reference lists there are relatively few references beyond 1989, which is not uncommon for a book such as this but it is no beyond the wit of man to update the chapter during the final editing process. There is, however, one notable exception, namely the editor's own chapter on 'Intestinal ion transport mechanism' which is peppered with 1990 and 1991 references. Inevitably in a book of this nature there is overlap between chapters The mechanisms of action of bacterial enterotoxins, for example, are covered in at least three chapters at slightly different levels of sophistication. Cross-referencing is by no means exhaustive and thus the reader needs to be willing to search the index and the chapters themselves to glean all there is on bacteria enterotoxins and their mode of action. When searching for deficiencies in the text one is always biased and notices omissions close to one's heart. The discussion of short bowe syndrome, perhaps more accurately called intestinal failure, is brief and limited to children. High output jejunostomy is an important clinical problem and more is known about the pathophysiology of the condition and its treatment than appears in this text. Similarly, the possible role of serotonin in cholera toxin-induced intestinal secretion is mentioned in the basic science section of the book but serotonin antagonists for controlling intestinal secretion are not mentioned in the chapter on pharmacotherapy.

Despite these minor reservations this book should find a place on the shelves of all those interested in diarrhoeal diseases and is a must for biomedical libraries.

M J G FARTHING

Annual of gastrointestinal endoscopy. Edited by P B Cotton, G N J Tytgat, C B Williams. (Pp 175; illustrated; £60.) London: Current Science, 1991.

This publication is one of the Current Science series, which seeks to bring the reader up to date with a comprehensive review of the literature in a particular field for one year. In this issue the distinguished editors have involved established endoscopists from around the world to give a commentary on the literature in their particular field, and then at the end of each chapter a comprehensive list of references is given for 1990 .

The book is well illustrated with colour endoscopic photographs, and is reader friendly. It is clear that the publishers have made a real effort to produce the annual as early in the year as possible, even though this has led to a number of typographical errors especially in the tables, but the standard of presentation is high. The 16 chapters deal with all aspects of endoscopy, and because the whole literature is reviewed the reader is brought up to date, with useful, practical comments from the authors. Some areas are developing faster than others so there are a variable number of references cited and commented upon in individual chapters. For example, endoscopy and upper gastrointestinal bleeding is in a large chapter, well reviewed, with a balanced opinion expressed on the new techniques in an exciting area. The use of monitoring in endoscopy inevitably has an American bias from its American author The recommendations of the British Society of Gastroenterology, although well argued, are probably more practical for most endoscopists (Gut 1991; 32: 823)

Jerry Waye concludes the book in typical punchy style, critically assessing some of the things that we do. There is an interesting chapter on developments in endoscopic instrumentation which are likely to be with us in the near future. This book can unreservedly be recommended for all active gastrointestinal endoscopy units. It is an excellent way of being kept abreast of changes in techniques and their application. This is an unusual case where an annual subscription is recommended!

D G COI.IN-JONES

All titles reviewed here are available from the BMJ Bookshop, PO Box 295, London WC1H 9TE. Prices include postage in the UK and for members of the British Forces Overseas, but overseas customers should add $15 \%$ to the value of the order for postage and packing. Payment can be made by cheque in sterling drawn on a UK bank, or by credit card (Mastercard, Visa, or American Express), stating card number, expiry date, and full name. 